\title{
IUELTAL
}

\section{Understanding Teacher Identity Construction: Professional Experiences of Becoming Indonesian Montessori Teachers}

\author{
Indira Lusianingtyas Siswanto \\ Sanata Dharma University \\ e-mail: indira.lusia@gmail.com \\ Paulus Kuswandono \\ Sanata Dharma University \\ e-mail:kus@usd.ac.id
}

\begin{abstract}
:
This study sought to investigate the identity construction of Indonesian Montessori teachers. The research was done in two Montessori schools in Yogyakarta: Cosmic School and Universe School (pseudonyms). The participants involved in this research were eight teachers in total. The data gathering process employed questionnaire, classroom observation, interview, and written reflections. The findings have shed a light on the ways teachers develop their identities within Montessori's values and principles that they reflect and implement in their daily teaching practice. The findings of the research portrayed that there were four major salient principles influencing the identity formation of becoming Montessori teachers. They were movement and cognition, choice, interest, and teacher ways and child ways. Those principles and values were becoming teachers' guidance of creating professional working ethos. Montessori principles also influenced the teachers in the ways they perceived and treated the students. This study also revealed the undertaken agencies to hold identity as Montessori teachers. There were three broad themes to explain their agencies. They entailed the essence of building communication between teacher and parents, the significance of community support, and the importance of being well-prepared teachers. Based on the findings and discussion, some recommendations for future studies are also presented.
\end{abstract}

Keywords: Identity construction, montessori, teacher identity 


\section{Introduction}

\subsection{Background}

Choosing a career as a teacher requires multifaceted intense works and a strong sense of dedicated teacher identity construction. The process of professional identity construction calls into numerous components, such as self-values, beliefs, expectancies, content knowledge, pedagogical proficiency and skills, as well as social relationship that involves emotional interaction with students, peers, parents, and social community (Richardson \& Watt, 2018). Those challenging and dynamic teacher's attributes may cause long and difficult formation process on their identity.

The formation of identity involves the maturation of biological and psychological development. The development stages are also connected to the individual's interaction with the environment (Beijaard, Meijer, \& Verloop, 2004). Nowadays, the teachers' perspective on how the formation and development of identity through their lifespan becomes interesting study to examine because identity construction issue is experienced by the teachers in all educational fields (Anspal, Leijen, \& Löfström, 2019; Beijaard, Meijer, \& Verloop, 2004; Alberto \& Castañeda, 2011;Beauchamp \& Thomas, 2009). In Indonesia, teacher identity topic has gained much attention for many education researchers. For example, the teacher identity construction of Indonesian pre-service teachers can reflect their professional learning in the journey of becoming a teacher (Kasmiran \& Dharma, 2018; Kuswandono, 2013). Meanwhile, the experiences of foreign language pre-service teachers in doing micro teaching in a university and teaching practicum in school context can contribute the development of teacher identity (Riyanti, 2017; Riyanti \& Sarroub, 2016; Zacharias, 2016). The influence of government policy and the development of teacher identity is also discussed by Hapsari \& Budiraharjo (2019). The research investigates the implementation of zoning policy influences English teacher identity in the context of high and low-performing schools.

As explained above, teacher identity construction is developed by various entities in which the teachers in all educational fields experience and endeavor to construct. Montessori school is one of the educational fields where the teachers are striving to build their identities within the principles. Montessori teachers are expected to equip themselves with particular roles residing in the principles, values, and the spirit of the method. As narrated by Christensen (2016), Maria Montessori, the founder of Montessori Method in the early of $20^{\text {th }}$ century, managed to arrange a mental, emotional, and spiritual figure for teachers as their preparation to teach young learners.

\subsection{Rationale}

The implementation of Montessori Method in Indonesia has developed special interest for many schools and researchers. According to Firdaus (2017), Montessori method is becoming popular in Indonesia as it entails brilliant ideas and methods that consider the student's pace of development. Indonesian researchers have investigated how Montessori Method can be applied into various educational fields (Kristiyani, 2019; Nisa, Ariyanto, \& Ahsyar, 2019). On one research, Kristiyani (2019) explores that not only can Montessori education be an option to be applied in inclusive education fields, the concept of Montessori environment and materials are also suitable to various ages and students' 
need. Aligning with the essential application of Montessori method, Nisa et al., (2019) examine that Montessori method can be used to understand Mathematics concept by involving all senses to ensure that children can grasp the math concept more optimally.

From those studies mentioned above, however, none has sufficiently discussed teacher identity construction of Montessori teachers. The urgency of discussing teacher identity in Montessori context is mainly because Montessori's fundamental philosophy can influence the teacher's ways to work in the classroom, and it will be the teacher's basic values and beliefs in their teaching practice (Malm, 2014).

\subsection{Research Questions}

Based on the rationale mentioned above, this study aims to answer two research questions. They are:

a. What Montessori principles transform the teacher identity?

b. What agencies are undertaken to develop the identity as Montessori teachers?

\section{Literature Review}

\subsection{Teacher Identity Concept}

The topic of teacher identity has intensely been discussed in the educational research for years (Akkerman \& Meijer, 2011; Izadinia, 2013; Yazan, 2019). Teacher identity is constructed dynamically, and multidimensional (Richardson \& Watt, 2018; RuohotieLyhty, 2018). Richardson \& Watt (2018) assert that there are some factors influencing the individual's experience in enacting identity through the lifetime, namely occupation, spirituality, ethnicity, and gender. In the same vein, Izadinia (2013) puts them into four detailed factors influencing teacher identity construction. They are (a) reflective activities, (b) learning communities, (c) context, and (d) (prior) experience as delineated below.

Reflective activities may provide hindsight into teachers' own values, beliefs, feelings, teaching practices and experiences to shape the teacher identity (Izadinia, 2013). Based on her findings, there are some activities included as reflective activities, such as writing reflective journals or logs, having classroom discussion, joining online-seminar groups or reading group forums. As for learning communities, Izadinia (2018) emphasizes the oneon-one relationship among teacher, mentor, and colleagues form the effectiveness of becoming a teacher. Ticknor (2014) states that workplace situation influences the formation of teacher identities. The finding of the study reveals that the more negative of the environment, the more rule governed, and the less creative the teachers are. The positive support from mentors and peers give personal strength, that eventually shape one's understanding of becoming teacher (Alsup, 2016; Izadinia, 2018; Ticknor, 2014). In context factor, Izadinia (2013) concludes that the context of learning can develop teacher's perseverance and a sense of agency at managing sites of conflict and tension. Findlay (2006) is verifying the relation of both learning factors (e.g., confidence, commitment, feedback and support) and context factors (e.g., allocation and structure of work and relationship with people at the working place) impact on identity construction of a qualified teacher. The last contribution of identity construction factor is (Prior) Experience. Izadinia (2013) suggests that values, beliefs and prior learning and experiences teacher brings to the working field are considered as considerable part in enacting their practice of 
teaching and identity. Avraamidou (2016) demonstrates that learning and experience are the important components in terms of teacher's life trajectories and ecological transactional.

\subsection{Teacher Agency Overview}

Teacher agency becomes one of the main concerns in investigating identity construction of Indonesian Montessori teachers. Seminal studies propose that the emergence of agency is as a way to produce identity (Alsup, 2016; Beauchamp \& Thomas, 2009; Ruohotie-Lyhty, 2018). Playing the roles as the agent of change, the teacher acts actively in the process of learning and gives contribution to the students, colleagues, school, or even the society (Bourn, 2015), and critically take an action in conflict situation (Biesta \& Tedder, 2014).

However, teacher agency is not constructed instantly. Its enactment takes a long process and depends upon some factors. According to Emirbayer \& Mische (1998), the factors of teacher agency are classified into three temporal dimensions. They are called the iterative, the projective and the practical evaluative, suggesting the benchmark to understand the enactment of teacher agency. Even though, Emirbayer \& Mische (1998) contend that the three dimensions of chordal triad of agency can resonate separately, they are not always in harmonious tones. To explain this spectrum, Priestley, Biesta, \& Robinson (2013) developed a model to guide data collection and assist data analysis. The model of teacher agency achievement is presented as follows.

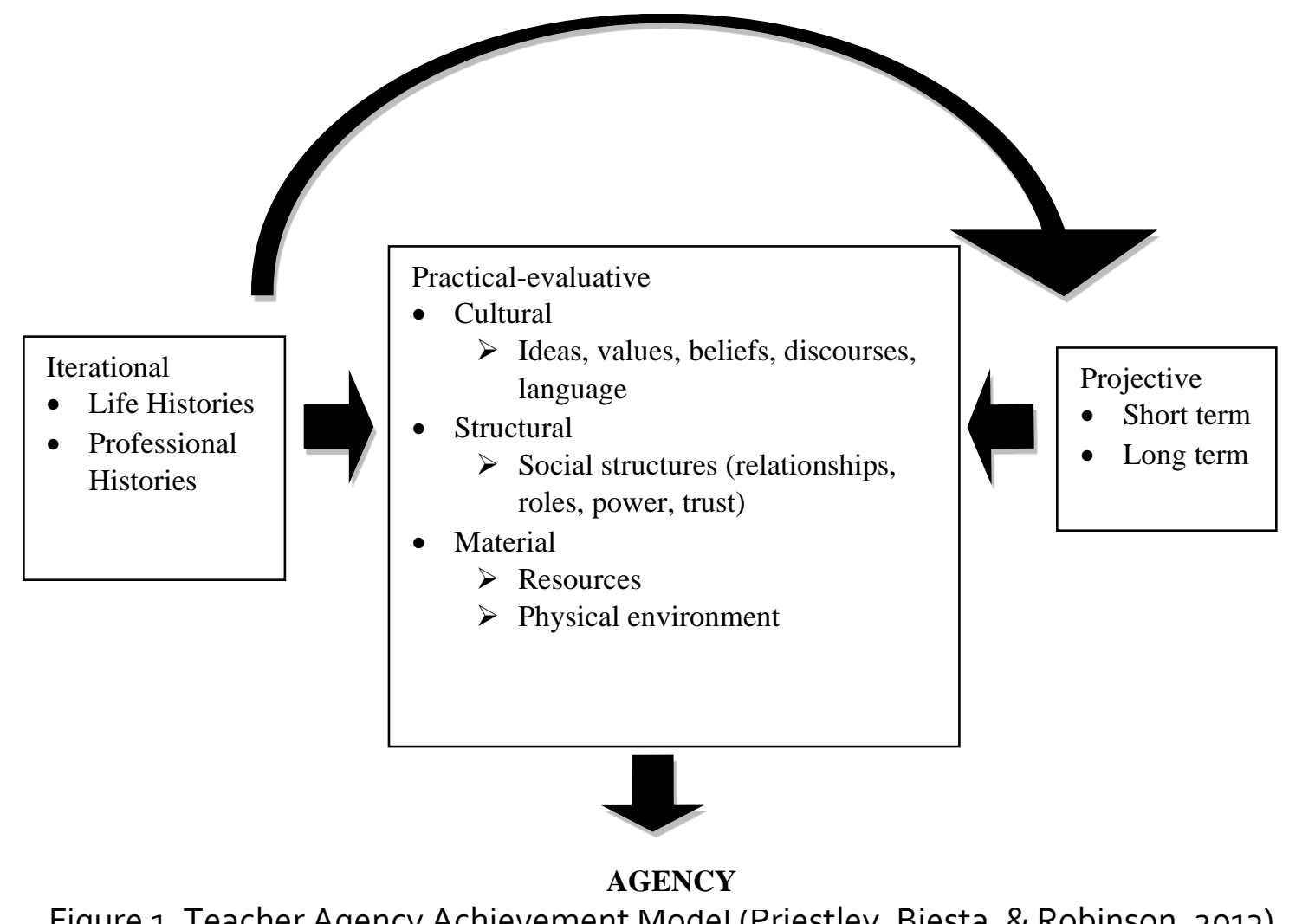

Figure 1. Teacher Agency Achievement Model (Priestley, Biesta, \& Robinson, 2013)

The above model describes the three different dimensions that give contribution to teacher agency achievement. The first dimension is iterational. According to Priestley, 
Biesta, \& Robinson (2013), this dimension is influenced by teacher's general histories of and their professional histories. The second dimension is projective. Emirbayer \& Mische (1998) assert that Projective dimension encompasses teacher' actions toward possible future trajectories. It also includes teacher's action and thought to reconfigure hopes, fears, and desires for the future. The third dimension is Practical-evaluative. This dimension entails the teacher's capacity to make practical and normative decision among the alternative possible actions in regard to the dilemmas, demands, and ambiguities to the current situation (Emirbayer \& Mische, 1998).

\subsection{Montessori Principles}

Montessori school is considered as the setting of the study. The major point to be discussed in this study is how the existing principles in Montessori curriculum can activate the teacher's characteristics in their daily teaching practices. Montessori curriculum is originated and created by Dr. Maria Montessori, an Italian physician who lived from 18701952. Montessori Method was initiated in 1907, when Dr. Maria Montessori was invited to open child-care place for fifty preschool-aged in Rome that was avoided and neglected due to family's poverty and criminal issues (Seldin \& Epstein, 2003).

According to Lillard (2016) there are eight underpinning principles in Montessori Method, namely movement and cognition, choice, interest, extrinsic rewards are avoided, learning with and from peers, learning in context, teacher ways and child ways, order in environment and mind. This section will clarify four, out of eight of principles, as they are most relevant to this research.

The first principle is "movement and cognition". Montessori argues that children's mental development must be connected with movement and make them dependent (Montessori, 1967). Montessori believes that when child moves with a purpose, there is a sense where child's body is associated with her/his thought. Thus, it can be drawn a conclusion that thought guides action (Lillard, 2016).

The second principle is "choice". One of the important principles which distinguish Montessori Method from other methods is the freedom to choose. Montessori children are allowed to make more decisions than are children in traditional classrooms. Children in Montessori classroom freely choose their activities (Lillard, 2016). Further, she adds that by having free choice, students are able to perform and feel better. On the other hand, Ling Koh \& Frick (2010) state that philosophy Montessori education is helping each child to attain self- mastery and autonomy in gaining students' competence and building students' intrinsic motivation.

The third principle in Montessori Method is "interest". Montessori (1967) argues that the secret of success in education is through stimulating students' imagination and interest. Montessori education allows the children to naturally choose to do what interest them (Lillard, 2016). Types of interest can be classified into two: personal interest and topic interest. Personal interest is related to something subjective, such as hobbies. Meanwhile, topic interests have wider area and are shared by many people.

The fourth principle is "teacher ways and child ways". Montessori argues that teacher's behavior aligns to students' outcomes. Therefore, Montessori school teacher should behave and interact properly to the children (Lillard, 2016). In this case, teacher-student 
attachment is the important component to build a good bonding between them and results to way teacher and student interaction (Lillard, 2016).

\section{Research Methodology}

Sequential mixed method was applied for this research (Creswell, 2014). It involved collecting quantitative data first, then explaining the quantitative result with in depth qualitative data. In quantitative method, the researchers distributed questionnaire to 15 participants which aimed to provide prior information about research topic that would be investigated, and to obtain participants' background information. Qualitative method was conducted as a follow up to the quantitative results. Since the researchers concerned to the accounts of participants' experiences and lived stories, narrative inquiry was selected to elicit data from the participants. Moreover, narrative inquiry can also promote teacher self-reflection through their voices (Ary, Jacobs, Sorensen, \& Razavieh, 2010). Conducting classroom observation from two teachers in Cosmic School (pseudonym) was the first method to obtain the data. Field notes and classroom observation checklist helped the researchers to capture the information during the teaching-learning period. The next phase was having interview session with 8 participants from Cosmic School and Universe School (pseudonym). In the last phase of data gathering process, the researchers required the participants to write reflection. Eventually, those four research instruments were employed to complete the richness of the data. They were also undertaken to triangulate the data information from the participants that might have not been captured in the interview.

The data gathering process was conducted from February 2020 to March 2020. The research was done in two schools: Cosmic School and Universe School (pseudonym). Both schools implemented Montessori Method as the approach to teach the students. Eight participants were selected with purposive sampling and they expressed the consent to participate in the research voluntarily. The participants were selected based on the length of teaching experiences, namely, those who had more than 2 years of implementing Montessori principles. The table below showed the participants' profile:

Table 1. Participants' Profile

\begin{tabular}{|c|l|l|c|c|c|l|}
\hline No & Name & $\begin{array}{c}\text { Name of } \\
\text { School }\end{array}$ & Gender & Age & $\begin{array}{c}\text { Years of } \\
\text { experience }\end{array}$ & Educational Background \\
\hline 1 & Teacher 1 & Cosmic & F & 32 & 12 years & Psychology Department \\
\hline 2 & Teacher 2 & Cosmic & M & 27 & 4 years & English Literature \\
\hline 3 & Teacher 3 & Cosmic & F & 28 & 4 years & $\begin{array}{l}\text { German Education Study } \\
\text { Program }\end{array}$ \\
\hline 4 & Teacher 4 & Cosmic & F & 25 & 3 years & $\begin{array}{l}\text { Young Learners Education } \\
\text { Study Program }\end{array}$ \\
\hline 5 & Teacher 5 & Cosmic & F & 37 & 8 years & English Literature \\
\hline 6 & Teacher 6 & Universe & F & 44 & 17 years & $\begin{array}{l}\text { English Education Study } \\
\text { Program }\end{array}$ \\
\hline 7 & Teacher 7 & Universe & F & 43 & 15 years & $\begin{array}{l}\text { English Education Study } \\
\text { Program }\end{array}$ \\
\hline 8 & Teacher 8 & Universe & F & 42 & 10 years & English Literature \\
\hline
\end{tabular}




\section{Findings and Discussion}

As noted in the background of the section, this study seeks to explore teacher identity construction of Indonesian Montessori teachers. Two research themes are elaborated in the discussion, namely Montessori principles which transform their identity in the process of becoming a teacher and the agencies which the teachers undertake to develop the identity as Montessori teachers.

\subsection{Montessori principles and teacher identity construction}

By involving in Montessori community during the data gathering process, the researchers arrived to a better understanding on the meaning-making process of becoming Montessori teachers through their life, work experience, and reflection. The participants interpreted that Montessori's fundamental principles influence their values and beliefs in their teaching practices. Those convictions are their guidance of creating professional working ethos which they reflected as the spirit of their daily working habits. Eventually, those convictions, values, and principles to become Montessori teacher are the supporting self-esteem or dignity of teacher characters.

According to Lillard (2016), there are eight underpinning principles in Montessori classroom. Montessori teachers try to immerse themselves with those principles in their daily teaching practice. Hence, the principles develop the tendencies to construct the identity of the teachers. The findings of the study portray that there are four major principles influencing the identity formation of becoming Montessori teachers. The table is shown as follows.

Figure 2. Montessori Principles as Perceived by the Teachers
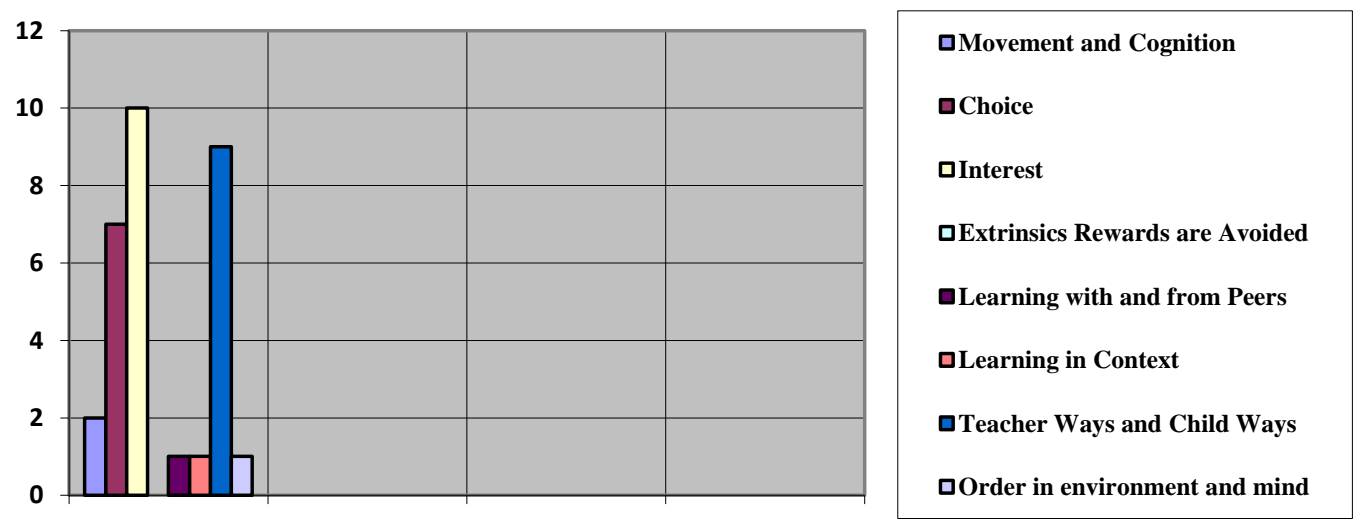

Based on the diagram above, it can be perceived that movement and cognition, choice, interest, and teacher ways and child ways are chosen as the salient components influencing identity formation as Montessori teachers. Meanwhile, the other four principles are considered to have lower influences. This, however, does not imply that those components do not play important roles in Montessori education. Rather, they display the variety of participants' inclinations as indicated in the interview, reflection, and classroom observation. 


\subsubsection{Interest}

One of the significant principles to promote students' learning motivation is by allowing the students to pursue their personal interest in learning. The typical habit of Montessori classroom is that the children can choose their work all day long, and it can arrive to their interest. Lillard (2016) argues that even in preschool, interest seems to build cognition and affects motivation to children. Teacher 1 , Teacher 8 , and Teacher 5 maintain that children can learn and grasp the learning materials more optimally when they can involve themselves to the topics and issues that fascinate them.

In Montessori, the teacher is taught that children have their own potential. If the teacher expects the child to be someone, so treat them right (Teacher 1)

Child centred approach puts children's right and interest above the adult's interests Teacher supposed to be able to support children's interest in order to develop according to their own uniqueness (Teacher 8).

We have to be sensible to students' interest. For instance, if they are fond of Science, we can give them more extended science learning needs. It is called as respecting the child (Teacher 5)

In whilst activity, the teachers are also consistent to the above philosophy as they provide solaces and opportunities for the children to choose what activities they appeal (Observation in Kindergarten). It shows that the teacher try to impress the students to pursue their interest in Montessori classroom through their activities. Dewantara, as a founding father of Indonesian education also supports to the importance of promoting interests for the students. It is asserted that a child lives as an individual and human being so that they grow along with their nature and interest. Hence, the educators' task is to guide their power (Dewantara, 2009).

\subsubsection{Teacher Ways and Child Ways}

The other valuable principle from Montessori education is the teacher ways and the child ways. It can be defined as teacher-student's interaction and behaviour that are able to influence the learning outcome. One study showed that children who were securely attached by their mother were becoming more capable in solving the problem, more persistent, more enthusiastic, and more obedient to her mother. Meanwhile, Montessori is consistent with authoritative parenting style in which the students receive high control, and high warmth from the teacher. Additionally, providing freedom within boundaries can be tremendously impactful to the children (Lillard, 2016). Allowing freedom to occur in the classroom can be seen from one of the teachers' experience below:

In my opinion, Montessori teachers treat children as a whole. We do not act as a superior. "Do that because I told you so" is not a good way to respect students in learning. Meanwhile, Montessori teaches us to consider children's potential. If the teachers expect the children to be "someone", so treat them right (Teacher 1.)

The teacher's belief above shows that one of significant aspect to educate the children is teacher's way in treating the children. For this case, Montessori philosophy is against authoritarian model. According to Lillard (2016), authoritarian parenting style is giving high demands to the children and not showing affection of them. Hence, authoritarian 
teachers are like to act "Do the task because I ask to" without providing valuable reason behind it.

Whereas, observing the children and finding their needs can be the fundamental foundation to good Montessori teaching. McTamaney (2012) asserts that ideal Montessori teachers are required to be scientists to observe the students' work and to be more prepared in responding the students' need and uniqueness. Regarding the significance of doing observation, the practices of two teachers below can be the proof:

As a teacher, we must observe attentively towards barriers faced by the student. If the students cannot read and write (for example), we can monitor and practice about letters and words with them. We also can communicate to the parents (Teacher 6).

When I experienced teaching in non-Montessori school, the Montessori exposure was brought along during my teaching. One most valuable principle was observation ability (Teacher 2).

Doing observation was so crucial for both teachers and students. In this case, the teacher is required to be more sensible to the students' needs and able to create better understanding to the students' necessity of learning. Lillard (2016) explains that sharp observation enables the teachers to develop understanding so that they can evaluate children behavior and can precisely support their needs.

\subsubsection{Choice}

The second preferred principle is choice. Choice becomes one of predominating principles in running Montessori class. In the morning, the students arrived in the classroom and chose freely what they wanted to work on. According to Lillard (2016), choice promotes some benefits that it relates to a sense of control in which human's well-being is enhancing. Aligned with the previous statement, statements from Teacher 1 and Teacher 4 support the ideas:

Montessori education allows the child to choose what activities they are going to do. In addition, it is good as this facilitates them in learning. Then, the student centered learning is more realistic to be applied (Teacher 1).

The students are allowed to choose the activities based on what they like within limits (Teacher 4).

It can be inferred from two teachers' statement that the importance of making choice of the students is able to promote their independence so that the students are more regulated and autonomous in their learning process. Therefore, autonomy support has positive impact on perceiving students' competence and intrinsic motivation. Empowering student's independent thinking, encouraging self-initiation, and respecting students' voice can be the ways to foster students' cognitive autonomy (Ling Koh \& Frick, 2010). However, developing students' autonomy must be supported by teacher's active role in nurturing the students about the importance of being independent. Based on the observation, the researchers found that the students were easily distracted and not focused on the task. 


\subsubsection{Movement and Cognition}

Movement and Cognition is one of the important selected principles. Some experts agree that cognition is embodied (Lillard, 2016). According to Wilson \& Golonka (2013), embodied cognition refers to the fact that the body state influences the mind state. Further, it is asserted that the brain is not only cognitive resource to solve problems. In fact, our bodies and their motions do much a lot of works for people to attain their goals (Wilson \& Golonka, 2013). Teacher 8 supports this philosophy:

When students have freedom to move, their learning is escalating. Because what the hands do, what the mind remembers (Teacher 8).

Based on the classroom observation, students' movement became one of the most significant aspects in conducting Montessori class. The students were able to choose the activity from the apparatus shelf during the learning hours. Moreover, in Montessori class, the students were having opportunity to experience outdoor investigation during the break time. They went to the field to catch some insects. The researchers found out that outdoor exploration did not solely allow the students to learn science, or environment. However, it can facilitate the students to learn more extensively about teamwork and problem solving. Some studies have portrayed that implementing movement in the classroom impacts positively to students' behavior and promotes their focus, calmness, and learning engagement (Akkerman, 2014). Nevertheless, a study reveals that physical activities and cognition can produce mixed results, in which physical activity contributes small positive influences on cognition, academic attainment and learning behavior (DalySmith et al., 2018).

Researchers have documented some supportive accounts for Montessori education. However, there are also some opposing ideas among the education practitioners in Indonesia. The arguments are usually centered around the practices since Montessori method cannot be easily implemented well within Indonesian educational system. Also, some researchers criticized about implementing Montessori method in Indonesian context based on Islamic perspectives (Gumiandari et al., 2019). The findings shed a light that Montessori Method does not emphasize the spiritual aspect, but more on the cognitive, affective, and psycho-motor aspects. Moreover, the avoidance of rewards and punishment are not in line with Islamic psychology. Rewards can foster students' motivation and punishment can direct the children to the self-discipline. The last is related to the parents' financial capacity to send the children in Montessori schools due to the school fee issues. The critics about Montessori concept also happened outside Indonesia. In the U.S, in the early of Montessori movement, it remained as a delusive and difficult method to understand (Lillard, 2018).

\subsection{Agencies employed by the teachers}

For the rest of the section, the researchers seek to answer the second research question regarding the teachers' undertaken agency to develop the identity as a Montessori teacher. This section presents a framework on what strategies and attempts were carried out as Montessori teachers. Three major themes are discussed to shed light on better perception of the teacher agency implementation. 


\subsubsection{The significance of communication building between teacher and parent}

Teachers and parents are the best support system for children to help them grow and flourish in all aspects. Hence, it is central to build good interaction between teacher and parent to support students' progress and long-term success. The participants of the research reveal some of the strategies how to communicate with the parents effectively during the academic year. The teachers reveal some important notions on how vital the communication building is.

Reporting students' progress and advice in regular PTM (Parent-Teacher Meeting) is important and effective way to build communication. I more highlight on the consistency in doing parenting style at home in line with the school habits (Teacher 5).

Parents' complain grows me to be a better teacher. I can evaluate myself as a teacher. I learn to communicate wisely, do the public speaking and learn to treat the children better (Teacher 6).

I write on my teaching diary to note students' behavior and its treatment. Therefore, I have the proof, in case the parents need the notes (Teacher 7).

The above evidences from teachers impart the significance of consistency in doing parenting style, judicious response to Parents' complaints, as well as students' behavior and its treatment. All of the experiences were noted and evaluated by the teachers for their self-reflection. Based on the two statements from the participants, doing reflection is a crucial way to resolve problems in repairing communication with the parents. Kuswandono (2012) asserts that reflection can promote teachers to train their mind and evaluate learning experiences.

\subsubsection{Community support to construct teacher agency}

Teacher and the community becomes reciprocal unity in the formation of agency. The school management also takes part in supporting teacher encountering the challenges and problems by conducting programs and training for them. The notions from Teacher 5 , and Teacher 6 are the evidences on how influential the community support is:

We have partners in class; students are our partners too. They also can be a peer control for other students. Thus, we remind each other (Teacher 5).

Joining workshop and seminar are the school ways to improve my professionalism. One of impressive moment was joining workshop in one Montessori school in Jakarta for two weeks. Then, in what follows, it can be adapted and adopted to our own school context (Teacher 6).

Kinds of positive support from colleagues and school have been identified as one of components to emerge teacher agency. It brings to comfortable and supportive environment so that teachers can work optimally. Izadinia (2016) highlights that continuous successful mentoring comes from positive and strong relationship with trust and respect among the teachers.

Agencies as experienced by the above Montessori teachers can be considered as a salient dimension of teacher's professionalism. Even though those teachers are in a conflicting situation, they endeavour to proactively look for solutions by positively influencing the 
environment, finding the problem core, or by changing the workplace as a means to achieve professional development condition (Ruohotie-Lyhty, 2018). Understanding agency can help teachers to be more reflexive (e.g., using teaching diary) and creative, and assist them to handle societal restrictions (Priestley, Biesta, \&Robinson, 2013), as evidenced in parent-teacher meeting.

\subsubsection{The vital role of being well-prepared teacher}

Montessori always emphasizes the significance of well-preparedness in the classroom. It involves prepared environment and structured lesson content (Lillard, 2016). Accordingly, the teacher as the manager of the classroom should plan and manage the classroom and the materials contextually and orderly. Properly planning and preparing the materials will affect the students' learning progress and teacher's time management. Consequently, teachers are more equipped and ready to transfer the piece of good content knowledge for students in the teaching-learning practices. Based on the participant's explanation, coaching can be the school culture to sustain teacher's teaching motivation, and keep on updating to current pedagogical issues and curriculum. It is beneficial for both coaches (coordinator) and teachers to strengthen their relationship and together construct shared knowledge among them (Robertson, 2016). Teacher 5 and Teacher 7 share their experiences on the ways they prepare and plan the content lesson:

We held regular meeting to discuss monthly lesson plan with our partners, teacher coordinator, and principal (Teacher 5).

In the monthly regular meeting, we receive a whole feedback related to our teaching lesson and presentation from the principal and coordinator (Teacher 7).

Having regular meeting and having coaching with the coordinators are the ways of the teachers to escalate their professionalism and to plan structured and prepared to the materials. According to (Lillard, 2016) Montessori education is tremendously organized and ordered, especially at the curricular level. In terms of material and content lesson, for children ages 3 to 12 , they are designed with reference to the complete set across all topics. Meanwhile, in terms of physical, Montessori classroom is very structured, with only necessary items in view. Structured and organized material and classroom is significant because Montessori believed that organized stuffs can promote free child development which is imperative for their internal development. Moreover, Darling-hammond, Hyler, \& Gardner (2017) propose that some effective teacher professional development should provide supportive collaboration which creates a forum for teachers to share and collaborate for learning improvement and, accordingly, creates positive communities to change school culture.

Regarding to one study done by Christensen (2016), the findings portray that the current Montessori discourses have not provided sufficient important information about the characteristics of teacher-lived experience. Moreover, acknowledging the social changes, Montessori teachers need to have teaching preparation, support system and leadership decision. Therefore, the findings of the research are expected to shed a light on the factors and components influencing the transformation of Montessori teacher identity that has not been discussed thoroughly by educational researchers. The findings about teacher 
agency are also expected to give better understanding for Indonesian teachers that developing identity requires authority, integrity, and strong-will from the teachers.

\section{Conclusion}

\section{1 Summary}

Teacher identity construction has been the salient topic to discuss because it is the process of making meaning on how teachers define or redefine themselves in the context of pedagogical proficiency. To conclude, Montessori teachers brought the principles of Montessori as the values and spirit of their working habits. The teachers admit that the principles became their characters in teaching and it might distinguish and make them unique from the other teachers. This research found out that there were four significant Montessori principles influencing the identity formation as Montessori teachers. The four major principles were movement and cognition, choice, interest, and teacher ways and child ways. Meanwhile, there were the other four principles that had lower influences for the teachers. However, it did not indicate that the other four principles were less superior to the other four salient principles as perceived by the teachers.

In dealing with the undertaken agencies, the researchers found that there were three kinds of agency which the teachers undertook to meet their goals and expectations as a Montessori teacher. The first was maintaining communication between teacher and parents to build a strong relationship and to keep up with students' progress. The second was asking and receiving support from the community. They believe that colleagues and school management are the best support system in conducting their profession as a teacher. Finally, the teachers were equipping themselves with coaching, group discussion and regular planning to be a well-prepared teacher.

\subsection{Future Studies}

Montessori education prescribes a set of principles for the teachers to be carried out encompassing strong dedication and commitment to run a role as an authentic Montessori teacher. However, enacting teaching commitment requires a long and difficult journey that forces the teachers to deal with a conflicting situation from personal and professional dilemma. With regards to the results, the researchers propose some prospective future studies to be done in the context of teacher identity construction.

Reflecting the authority and vulnerability of becoming Montessori teachers can be worthwhile. Vulnerability and authority topic has a strong relation to identity construction. It is a way for teachers to respond, to balance and re-balance the conflict and challenges within divergent situation. The second prospective topic is investigating the critical incidents in the process of meaning making as a Montessori teacher. Critical incident can be valuable and meaningful reflections for teachers because they can analyze the lessons and make them as a powerful change for their professional development. The two topics that have been mentioned by the researchers are fundamental for the development of teacher identity because they are closely related and experienced by the teachers in almost all educational settings. By bringing up vulnerability and authority, as well as the teachers' authentic experiences of critical incidents, future researchers can investigate how the teachers cope with conflicting situations and how they develop themselves amidst the educational constraints as a professional teacher. 


\section{References}

Akkerman, A. (2014). Benefits of Movement in a Montessori Classroom on Children's Behavior and Focus Advisor's Signature.

Akkerman, S. F., \& Meijer, P. C. (2011). A dialogical approach to conceptualizing teacher identity. Teaching and Teacher Education, 27(2), 308-319. https://doi.org/10.1016/j.tate.2010.08.013

Alsup, J. (2016). Teacher Identity Discourse as Identity Growth : Stories of Authority and Vulnerability. 13-23. https://doi.org/10.1007/978-3-319-93836-3

Anspal, T., Leijen, Ä., \& Löfström, E. (2019). Tensions and the Teacher's Role in Student Teacher Identity Development in Primary and Subject Teacher Curricula. Scandinavian Journal of Educational Research, 63(5), 679-695. https://doi.org/10.1080/00313831.2017.1420688

Ary, D., Jacobs, L. C., Sorensen, C., \& Razavieh, A. (2010). Introduction to research in education eight edition. Wadsworth: Cengage Learning.

Avraamidou, L. (2016). Studying Science Teacher Identity Theoretical, Methodological and Empirical Explorations. Retrieved from https://link.springer.com/chapter/10.1007/97894-6300-528-9_1

Beauchamp, C., \& Thomas, L. (2009). Understanding teacher identity : an overview of issues in the literature and implications for teacher education. 3577(May). https://doi.org/10.1080/03057640902902252

Beijaard, D., Meijer, P. C., \& Verloop, N. (2004). Reconsidering research on teachers' professional identity. Teaching and Teacher Education, 20(2), 107-128. https://doi.org/10.1016/j.tate.2003.07.001

Biesta, G., \& Tedder, M. (2006). How is agency possible? Towards an ecological understanding of agency-as-achievement. Learning lives: Learning, identity, and agency in the life course.

Bourn, D. (2016). Teachers as agents of social change. International Journal of Development Education and Global Learning, 7(3), 63-77.

Christensen, O. (2016). Proving Montessori: Identity and dilemmas in a Montessori teacher's lived experience. Journal of Montessori Research, 2(2), 35-48.

Creswell, J. W. (2014). A concise introduction to mixed methods research. California :SAGE publications.

Daly-Smith, A. J., Zwolinsky, S., Mckenna, J., Tomporowski, P. D., Defeyter, M. A., \& Manley, A. (2018). Systematic review of acute physically active learning and classroom movement breaks on children's physical activity, cognition, academic performance and classroom behaviour: understanding critical design features. 1-16. https://doi.org/10.1136/bmjsem-2018-000341

Darling-Hammond, L., Hyler, M. E., Gardner, M. (2017). Effective Teacher Professional Development. Palo Alto, CA: Learning Policy Institute.

Dewantara, H. (2009). Menuju manusia merdeka. Yogyakarta: Leutika.

Emirbayer, M., \& Mische, A. (1998). What is agency?. American journal of sociology, 103(4), 962-1023.

Findlay, K. (2006). Context and learning factors in the development of teacher identity: a case study of newly qualified teachers during their induction year. Journal of InService Education, 32(4), 511-532. https://doi.org/10.1080/13674580601025165 
Firdaus, I. (2018). The Application Of Montessori Method To A Child's Development In English Reading And Writing Skills (Case Study). Pujangga, 3(2), 35.

Gumiandari, S., Cirebon, K., Barat, J., Cirebon, K., Barat, J., Jamaluddin, D., \& Barat, J. (2019). Criticizing montessori's method of early education using islamic psychology perspective childhood. 5, 133-148. https://doi.org/10.15575/jpi.v5i2.5835

Hapsari, A. G. S., \& Budiraharjo, M. (2019). English Teacher Identity in the Context of Zoning Policy Implementation. Journal of Educational Research and Evaluation, 3(4), 258-265. Retrieved from https://ejournal.undiksha.ac.id/index.php/JERE/article/view/23203/14254

Izadinia, M. (2013). A review of research on student teachers' professional identity. British $\begin{array}{llll}\text { Educational Research Journal, 694-713. } & \text { 39(4), }\end{array}$ https://doi.org/10.1080/01411926.2012.679614

Izadinia, M. (2016). Professional Development in Education Student teachers ' and mentor teachers 'perceptions and expectations of a mentoring relationship : do they match or clash ? 5257(March). https://doi.org/10.1080/19415257.2014.994136

Izadinia, M. (2018). Mentor Teachers. Contributions to the Development of Preservice Teachers 'Identity. 109-119.

Kasmiran, M. S., \& Dharma, U. S. (2018). Narrative inquiry: peers' feedbacks effect to identity construction of indonesian pre-service teachers. 1(2), 59-76.

Kristiyani, C. (2019). Materials and (language) learning environment based on montessori concepts. 21(1), 46-54. https://doi.org/doi.org/10.24071/llt.2018.210105

Kuswandono, P. (2012). Reflective Practices for Teacher Education. Language and Language Teaching Journal, 15(01), 149-162. https://doi.org/10.24071/lt.2012.150102

Kuswandono, P. (2013). The Journey of Becoming a Teacher: Indonesian pre-service teachers reflecting on their professional learning. Tesol, Doctorate(April), 314. Retrieved from http://arrow.monash.edu.au/hdl/1959.1/893044

Lillard, A. (2018). Preschool children's development in classic Montessori, supplemented Montessori , and conventional programs. (June 2012). https://doi.org/10.1016/j.jsp.2012.01.001

Lillard, A. S. (2016). Montessori: The science behind the genius. Oxford:Oxford University Press.

Ling Koh, J. H., \& Frick, T. W. (2010). Implementing Autonomy Support: Insights from a Montessori Classroom. International Journal of Education, 2(2), 1-15. https://doi.org/10.5296/ije.v2i2.511

Malm, B. (2004). Constructing professional identities: Montessori teachers' voices and visions. Scandinavian journal of educational research,48(4), 397 412.https://doi.org/10.1080/0031383042000245799

McTamaney, C. (2012). The tao of Montessori: Reflections on compassionate teaching. Lincoln: iUniverse.

Montessori, M. (1967). The absorbent mind (CA Claremont, trans.). New York: Henry Holt.

Nisa, T., Ariyanto, F., \& Ahsyar, A. (2019). Montessori learning : understanding the concept of early childhood mathematics Montessori learning: understanding the concept of early childhood mathematics. IOP Conf. Series: Journal of Physics: Conf. Series 1211 (2019) 012094, 1-9. https://doi.org/10.1088/1742-6596/1211/1/012094

Priestley, M., Biesta, G. J. J., \& Robinson, S. (2012). Teachers as agents of change: An exploration of the concept of teacher agency. 
Richardson, P. W., \& Watt, H. M. G. (2018). Teacher professional identity and career motivation: A lifespan perspective. In Research on Teacher Identity (pp. 37-48). Cham : Springer.

Riyanti, D. (2017). Teacher Identity Development : A Collective Case Study Of English As A Foreign Language Pre-Service Teachers Learning To Teach In An Indonesian University Teacher.

Riyanti, D., \& Sarroub, L. K. (2016). Indonesian Pre-Service Teachers' Identities in a Microteaching Context : Learning to Teach English in an Indonesian Teacher Education Program.

Robertson, J. (2016). Coaching leadership: Building educational leadership capacity through partnership. ERIC.

Ruohotie-Lyhty, M. (2018). Identity-agency in progress: Teachers authoring their identities. Research on Teacher Identity: Mapping Challenges and Innovations, 25-36. https://doi.org/10.1007/978-3-319-93836-3_3

Seldin, T., \& Epstein, P. (2003). The montessori way. Florida: Montessori Foundation Press.

Ticknor, A. S. (2014). Negotiating Professional Identities in Teacher Education: A Closer Negotiating Professional Identities in Teacher Education : A Closer Look at the Language of One Preservice Teacher. (November). https://doi.org/10.1080/1547688X.2014.965094

Wilson, A. D., \& Golonka, S. (2013). Embodied Cognition is Not What you Think it is. Frontiers in Psychology, 4(February), 1-13. https://doi.org/10.3389/fpsyg.2013.00058

Yazan, B. (2019). Toward identity-oriented teacher education: Critical autoethnographic narrative. TESOL Journal, 10(1), 1-15. https://doi.org/10.1002/tesj.388

Zacharias, N. T. (2016). Exploring identity construction of student teachers practicing ELF pedagogy in a microteaching course. (January). https://doi.org/10.1075/japc.26.2.08zac 